\title{
Post Prostatectomy Incontinence
}

\author{
Prostatektomi Sonrası Üriner İnkontinans \\ Aliseydi Bozkurt, Yiğit Akın, Barış Nuhoğlu \\ Department of Urology, Faculty of Medicine, Erzincan University, Erzincan, Turkey
}

\begin{abstract}
Urinary incontinence after prostatectomy for malignant and/or benign prostatic diseases is one of the most serious complications. Urinary incontinence occurs rarely after prostatectomy for benign diseases. However, it may occur more commonly after radical prostatectomy. These complications affect the patient's quality of life. Treatment of incontinence due prostatectomy includes several methods which differ from conservative to invasive surgical procedures. Slings and artificial urethral sphincters (AUS) are used more often than other procedures. Infection ratios and erosion of urethra are less frequent in AUS than in slings. Although AUS is the standard surgical procedure for severe urinary incontinence, slings may be used for severe male incontinence after prostatectomy due to the current development in sling materials.. Herein, we evaluate post prostatectomy urinary incontinence and treatments in the light of a review of current literature.(JAREM 2012; 2: 96-100)
\end{abstract}

Key Words: Male sling, radical prostatectomy, stress urinary incontinence, TURP

\section{ÖZET}

Benign ya da malign hastalıklar için yapılan prostatektomi sonrasında inkontinans gelişmesi en korkulan komplikasyonlardandır. Benign nedenlerle prostatektomi uygulanan hastalarda post operatif üriner inkontinans nadir iken, radikal prostatektomi sonrasında daha yüksek oranlarda görülür. Bu komplikasyon, hastanın yaşam kalitesini önemli derecede etkilemektedir. Prostatektomi sonrası oluşan idrar kaçırma tedavisinde; konservatif yöntemlerden, invaziv girişimlere kadar değişen farklı yöntemler kullanılır. Sling ve artifisyel üriner sfinkter (AÜS) operasyonları bu amaçla en sık kullanılan cerrahi tedavi yöntemlerdir. Sling yöntemleri, AÜS'e göre operasyon sonrası enfeksiyon ve üretral erozyon gibi komplikasyonları açısından düşük risk taşımaktadır. Şiddetli inkontinansta AÜS, günümüzde standart tedavi seçeneği sayılsa da, erkek sling materyallerindeki gelişmeler, ciddi inkontinans vakalarında da sling yöntemlerinin öne çıkacağını göstermektedir. Bu çalışmada prostatektomi sonrası idrar kaçırma ve tedavi yöntemleri güncel bilgiler eşliğinde değerlendirildi. (JAREM 2012; 2: 96-100)

Anahtar Sözcükler: Male sling, stres üriner inkontinans, radikal prostatektomi, TURP

\section{INTRODUCTION}

There should be an association between detrusor stability and closed bladder outlet for urinary continence in males. Urinary incontinence, which occurs after radical prostatectomy (RP), is associated with a bladder outlet that should be closed. The mechanism of the normal urethral sphincter in males has two functional parts: the proximal urethral sphincter (PUS) and distal urethral sphincter (DUS). PUS loses its function and only the continence of DUS continues after RP. In addition, intact neural innervation and the normal bladder functions should be intact for resuming urinary continence.

In this review, we evaluated the parameters of post prostatectomy incontinence; etiology, definition, risk factors, prevalence and treatment options of urinary incontinence after prostatectomy in the light of current literature.

\section{Etiology and Pathogenesis}

The proximal urethral sphincter is composed of 3 parts respectively; bladder neck, prostate and prostatic part of the urethra. Additionally, the borderline of the PUS extends to the verumontanum and is innervated by parasympathetic fibers originating from the pelvic nerves. This part loses its function after RP and only the DUS helps for resuming urinary continence (1). The DUS extends from the verumontanum to the proximal bulbar part of the urethra. Folds of urethral mucosa, rabdosphincter, extrinsic paraurethral skeleton muscles and supportive fascia join the structure of the DUS. Additionally, neural innervation of the DUS is carried out by autonomic fibers originating from the pelvic nervous system and somatic fibers originating from pudendal nervous systems (2).

The distal urethral sphincter resumes urinary continence after PUS has been destroyed by transurethral prostatic resection (TURP), open prostatectomy or RP. Direct injury to the DUS or neural innervations during surgery and/or previous injury, such as a history of radiotherapy or trauma, contribute to the development of urinary incontinence after prostatectomy (3). In this situation, incontinence can include a broad range from stress urinary incontinence, which occurs after increasing the intra-abdominal pressure, to total incontinence.

Stress urinary incontinence, which is caused by aggressive surgical techniques during TURP, is the result of injury to the sphincter by aggressive resection around the apex of the prostate and/or beyond the verumontanum.

Functions of the sphincter is reduced and/or ended by surgical removal of the verumontanum and apex of the prostate during RP.

The other factors for resuming continence are the existence of normal functions of the bladder, compliance and lack of detrusor over-activity. If there is bladder outlet obstruction before TURP 
or RP, the functions of the bladder may be impaired. Although most symptoms of an overactive bladder may be recovered by obviating the bladder outlet obstruction after the operation, the symptoms continue in $35 \%$ of the all patients (4). Additionally, independent from bladder outlet obstruction, the age levels of the patients affect functions of the bladder adversely. Excessive resection of the bladder neck during TURP or removal of a large part of the bladder neck during RP may cause urgency and/or urge incontinence in which the symptoms of overactive bladder occur by decreased compliance of bladder.

Overflow incontinence may occur after the operation (5). Large residual adenomas after TURP, contracture in the bladder neck and/or urethral stricture are the causes of overflow incontinence. The most common cause of overflow incontinence after RP is the anastomotic strictures in the bladder neck. The other reason is urethral strictures.

\section{Risk factors}

The age of patients, stage of prostate cancer, experience of the surgeons, urinary continence before operation, previous radiotherapy, previous operations and surgical technique are the well described risk factors for urinary incontinence after prostatic surgery (6). All of these mentioned factors cause the urinary incontinence after RP (6).

Neural degenerations and atrophy of skeletal muscles of the DUS are inevitable in elderly patients. Nilsson et al reported a high rate of stress incontinence after operation in patients at the age of 70 or older (7). Additionally, the occurrence of bladder dysfunction causes urinary incontinence in patients who are older than age of 70 .

Loeb et al. (8) compared the results of operations which were performed for localized or locally advanced prostate cancer and reported no statistical significance between them. However, the rates of incontinence are higher in locally advanced prostate cancer than localized prostate cancer in clinical practice, according to extensive surgical margins.

Paparel et al. (9) reported frequent urinary incontinence in patients who had undergone RP or palliative TURP with a history of previous radiotherapy.

It is proven that the surgical technique affects the urinary incontinence for prostate surgery for benign or malignant diseases. Nonaggressive resections in the apex of the prostate, determining the distal line as verumontanum during TURP, are the factors which can prevent urinary incontinence (10). O'Donnel et al. (11) described a nerve sparing technique in RP in 1989. Subsequently, some studies reported better continence with nerve sparing RP (12).

Parallel to the developing technology, laparoscopic and robotic surgeries are used in urological practice more frequently. In this way, pelvic anatomy has been understood better. Erdogru et al. (13) reported that better continence and erectile functions could be provided by minimal dissection of pelvic structures and nerve sparing techniques under optical magnification of laparoscopic and robotic surgeries $(14,15)$.

\section{Prevelance and Diagnosis}

The reported rate in the literature of urinary incontinence is $1 \%$ after TURP or open prostatectomy and 2-66\% after RP (16).
The diagnosis has two steps, as has been described in the guideline of the European Association of Urology (EAU) (17). In the first step; daily incontinence episode numbers, the effects of daily activities on incontinence, need for additional devices (penile clamp, pad), voiding schedule, previous history of incontinence before operation (8-27\%), radiotherapy (before or after operation), additional treatments such as brachytherapy, previous history of pelvic or urethral surgery and additional drug usage should be questioned in patients.

Detailed physical examinations, which include rectal and also neurological examinations, should be performed. Urinary incontinence by coughing or valsalva, perineal sense with deep tendon reflexes, anal sphincter tonus and bulbocavernosus reflexes should be evaluated. However, external paraurethral muscles (levator) are affected less by surgical traumas the ability to hold the urine during micturition is not very important.

In the laboratory, serum creatinine, urea, prostate specific antigen and urine analysis are important. Patients should undergo uroflowmetry for determining the maximum speed of micturition and also urine residue should be determined after micturition. Low speed in micturition may be an effect of obstruction and/or bladder dysfunction. There is no need to perform uroflowmetry in patients who are totally incontinent, because of lack of ability in urine stock-up. Level of incontinence can be determined by the pad test.

When the first evaluation is insufficient, advanced evaluations should be performed as the second step. Urodynamic tests which provide for performing differential diagnosis of bladder dysfunction and sphincteric insufficiency are helpful for determining the type of incontinence (18). Urine leakage and the pressure of the leak point should be determined with valsalva during the test. Abrams-Griffiths nomograms can also be used for this process (19). According to these nomograms, bladder outlet obstruction can be diagnosed easily. Cystourethroscopy, which can be used in selected patients, is another option for second step diagnosis (Figure 1). Urethral mucosa, anastomosis and the pathologies of bladder mucosa can be evaluated. Especially cystourethroscopy must be performed in patients who are scheduled for artificial urethral sphincter (AUS), sling or injection.

\section{Treatment}

The type of incontinence and its degree, the cause of incontinence, influence on quality of life and expectation from treatment must be considered before the treatment. Han and Lai reported that patients may develop urinary continence after the first year of prostatic surgery, so they proposed waiting for a year $(20,21)$. Although they reported waiting for a year, it is not valid for patients who have severe urinary incontinence and patients with poor quality of life.

Management of the treatment options from non-invasive to invasive is recommended in the EAU guideline as well as in literature (17).

\section{A) Non-invasive Treatment}

Exercises for pelvic muscles are the first step in treatment. It is performed by repeated contractions and relaxations of selective and optional pubococcygeus and levator muscles. The aim 


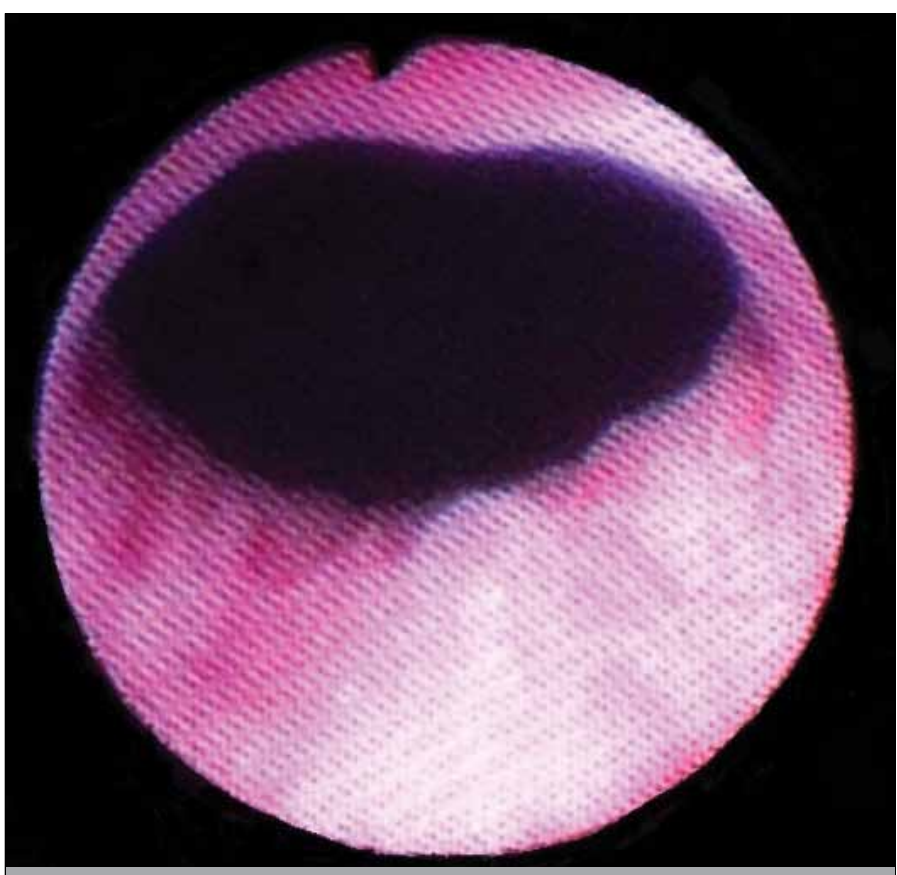

Figure 1. In cystoscopic view, resected urethral sphincter is on the line of verumontanum at the level of 12 o'clock

of these exercises is to strengthen the mechanism of urethral closure by increasing the strength of pelvic muscles. Filacamo et al reported the effectiveness of exercises on pelvic muscles and the benefits for urinary continence in the short-term period, but they also mentioned that these exercises had no long-term benefits for urinary continence (22). Daneshgari and Moy (23) reported positive results to enhance continence with electrical stimulations. Furthermore, restriction of fluid intake, reducing beverages which are bladder irritants, and timed voiding may be recommended to patients, but these types of treatments, which are not evidence-based, have no standardization and are very difficult to be performed by patients.

\section{B) Medical Treatment}

If there are overactive bladder symptoms in bladder dysfunction, anticholinergics, antimuscarinics, serotonin-noradrenaline reuptake inhibitors (duloxetine) may be used (24). Kuo et al. (25) reported that the usage of botox and capsaisin, reduced the symptoms of an over active bladder. Even though they were successful in reducing e the over active bladder symptoms, the necessity of repetitions and expense are disadvantages (26). Moreover, there are only a few studies in the literature (26). If there is a noncontractile bladder, clean intermittent catheterization should be recommended. If sphincteric dysfunction is diagnosed, alpha adrenergics and/or imipramin can be used. Noninvasive treatments, which are mentioned above, may be performed before and during medical treatment.

\section{C) Surgical Treatments}

If the patient wets one or two pads this is described as mild; two to five pads is described moderate; more than five pads is described severe urinary incontinence. The surgical treatment options depend on the degree of urinary incontinence respectively; collagen injection to DUS can be used for mild incontinence, AUS or slings can be used for moderate and severe uri- nary incontinence $(22,27)$. The surgical treatments for sphincter insufficiency should be performed after detailed examinations of patients. There are many reported results of these surgical treatments in literature.

Urinary diversions may come into question for patients who did not benefit from surgical treatments and severely impaired the quality of life. Additionally, if there is no successful effect on bladder dysfunction in the first step of treatment, the advanced surgical options may come into question, such as augmentation cystoplasty.

\section{Injection}

Use of injections in post prostatectomy incontinence is limited compared to incontinence of ladies. Collagen, silicon, teflon, carbon particles, autologous oil, durasphere, ethylene vinyl alcohol, polyetaphloretylene are used. Smith and et al. (28) revealed that the $60-70 \%$ success with injection in short-term period and the success rate decreases during the long-term period. Furthermore, Cespedes et al. (29) reported a $20 \%$ success rate for longterm period.

\section{Sling operations}

Slings have emerged as a new treatment model due to the high complication rates of AUS. Various sling materials and surgical techniques have been developed by using the model for the first slings which were firstly created by Berry (30), Kaufman (31) and Kishev (32). The aim is to cause pressure on the urethra. The pressure on the urethra can be provided by attaching to more stable tissues such as pubic bone, rectus muscle, obturator fossa, corpus cavernosum and thus complications may be prevented.

Comiter reported total continence with the rate of $68 \%$ and $80 \%$ total recovery of symptoms as a result of 48 bone anchor sling operations within 48 months follow-up (33). Guimarães et al. (34) announced similar results with the same method in a 28 month follow-up. The sling material produces pressure on the bulbous part of the urethra in the surgical method of bone anchor sling. The significant complications such as 3\% infection, less than $2 \%$ erosion of urethra, $16 \%$ perineal abscess which was recovered in 3 months were also reported in these studies.

Transobturator slings, which apply pressure to the membranous part of the urethra, draw the urethra up and thus the sphincter is moved into the pelvis. Sling material is inserted into the perineal space and is prolonged to the obturator space with helical needles. Grimsby et al. (35) reported a success rate of $78 \%$ in the short-term and also they revealed that obesity, radiotherapy and severe incontinence affect the healing adversely.

Recently, various adjustable male slings have been used frequently (Figure 2). The most important advantage of this process is that they are adjustable for tightening and widening after the sling operations. It consists of silicon foam pillows which are placed under the bulbous urethra and secured to the rectus fascia with silicone gaskets. Romano et al reported $83 \%$ success rates in a short-term follow-up, however, complications such as acute urinary retention may occur in the short-term period (36). Bleeding, infection, urinary retention, urethral erosion, pelvic pain are complications which may occur after surgery in the short-term follow-up. The risk rates of these complications are lower than AUS in slings. 


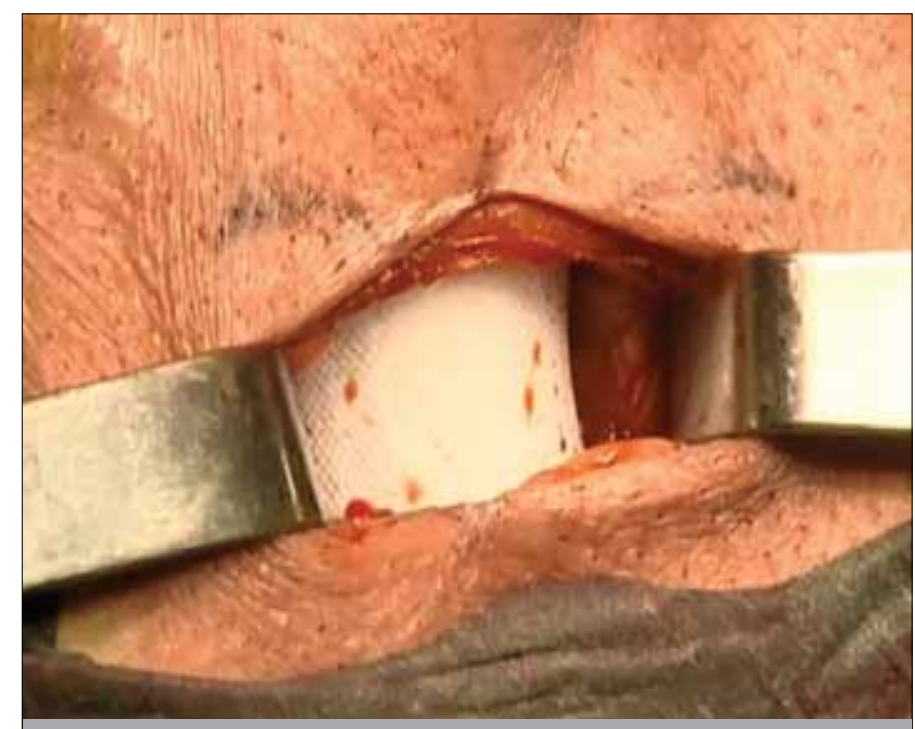

Figure 2. Perineal view of adjustable sling material. The sling material was placed at the bulbourethral junction

Trigo-Rocha et al. (37) reported $70 \%$ success of continence in a short-term follow-up with peri-urethral balloons which were placed in the transperineal using the guidance of fluoroscopy, urethroscopy or ultrasonography and was inflated $8 \mathrm{~mL}$ or until continence was achieved. Koncjancic et al. (38) reported a high rate of complication of periurethral balloons and also they removed the balloons from $17 \%$ of the patients.

\section{AUS}

Artificial urethral sphincters 800 were developed by Scott in 1983 and have also undergone several modifications up to the present (39). It is often used for surgical treatments in post prostatectomy incontinence. A cuff is placed in the bulbous urethra, the pump is placed into the scrotum and a reservoir is placed in the inguinal area. Tse (40) and Montague (41) reported 82-95\% success rates. Mechanical problems, urethral erosion, infections, hematoma and also retention are the most important complications and create restrictions in clinical use (41). Additionally, patients should be physically and mentally capable of using the pump of the sphincter manually.

\section{D) Others}

The gracilis muscle is transferred for muscle tissue transplantation. The gracilis muscle is transferred with an intact nerve and may mimic the urinary sphincter (42). Perez-Abadia et al. (42) transferred the cadaveric gracilis muscle to dogs and also hypothesized that this may be performed in humans but there is not enough study about the use of this method in humans.

Transobturator tape (TOT), which is used for stress urinary incontinence as a minimally invasive surgical option in women, is another treatment option for men. Rehder et al. (43) increased the functional length of the urethra and thus they achieved a decrease in urinary incontinence with TOT. In the literature, the lack of long-term results and studies are the most important deficiency of TOT application in men.

Another promising treatment is are stem cell treatment. The aim of stem cell treatment is to help in ensuring the biological functions of tissues or organs which were damaged, by fixing or renewing. The usage of skeletal muscle derived stem cells are recommended for incontinence and for providing the recovery of sphincter functions. Strasser et al. (44) injected the compound of fibroblast and collagen into the urethral submucosa in 130 patients. In this way they intended to configure the sphincter. Also they reported an increased diameter of sphincter and $85 \%$ success of the treatment. Although Mitterberger et al. (45) reported $65 \%$ cure and $27 \%$ recovery with injections of stem cell, the results were met with suspicion due to methodological flaws.

\section{CONCLUSION}

The treatment options for urinary incontinence which occurs after prostatectomy depend on many factors, respectively; quality of life of affected patients and degree and type of incontinence. Adjustable sling materials and AUS are the minimally invasive surgical treatment options for moderate and/or severe incontinence occur after prostatectomy. Slings have currently come into more use. Usage of stem cell may be promising in treatment.

Although there is no developed treatment with a success rate of $100 \%$, researches have still been continuing for less invasive and more effective treatments. More comprehensive studies with high standards should be performed to discover successful treatment options.

Conflict of interest: No conflict of interest was declared by the authors.

\section{REFERENCES}

1. Myers RP. Male urethral sphincteric anatomy and radical prostatectomy. Urol Clin North Am 1991; 18: 211-27.

2. Burnett AL, Mostwin JL. In situ anatomical study of the male urethral sphincteric complex: Relevance to continence preservation following major pelvic surgery. J Urol 1998; 160: 1301-6. [CrossRef]

3. Wilson LC, Gilling PJ. Post-prostatectomy urinary incontinence: a review of surgical treatment options. BJU Int 2011; 107 Suppl 3: 7-10. [CrossRef]

4. Leach GE, Yip CM, Donovan BJ. Post prostatectomy incontinence: the influence of bladder dysfunction. J Urol 1987; 138: 574-8.

5. Tomaschi W, Suster G, Holtl W. Bladder neck strictures after radical retropubic prostatectomy: Still an unsolved problem. Br J Urol 1998; 81: 823-6. [CrossRef]

6. Carlson KV, Nitti WW. Prevention and management of incontinence following radical prostatectomy. Urol Clin N Amer 2001; 28: 595-612. [CrossRef]

7. Nilsson AE, Schumacher MC, Johansson E, Carlsson S, Stranne J, Nyberg $T$, et al. Age at surgery, educational level and long-term urinary incontinence after radical prostatectomy. BJU Int 2011; 108: 1572-7. [CrossRef]

8. Loeb S, Smith ND, Roehl KA, Catalona WJ. Intermediate-term potency, continence, and survival outcomes of radical prostatectomy for clinically high-risk or locally advanced prostate cancer. Urology 2007; 69: 1170-5. [CrossRef]

9. Paparel P, Soulie M, Mongiat-Artus P, Cornud F, Borgogno C. Salvage radical prostatectomy after external radiotherapy for prostate cancer: indications, morbidity and results. Review from CCAFU prostate section. Prog Urol 2010; 20: 317-26. [CrossRef]

10. Hu K, Wallner K. Urinary incontinence in patients who have a TURP/ TUIP following prostate brachytherapy. Int J Radiat Oncol Biol Phys 1998; 40: 783-6. [CrossRef] 
11. O'Donnell PD, Finan BF. Continence following nerve-sparing radical prostatectomy. J Urol 1989; 142: 1227-9.

12. Steiner MS, Morton RA, Walsh PC. Impact of anatomical radical prostatectomy on urinary continence. J Urol 1991; 145: 512-5.

13. Erdogru T, Yucel S, Frede T, Baykara M, Rassweiler J, Teber D. Laparoscopic radical prostatectomy: transfer validity. Int J Urol 2010; 17: 476-82. [CrossRef]

14. Minniti D, Chiadò Piat S, Di Novi C. Robot-assisted versus open radical prostatectomy: an evidence-based comparison. Technol Health Care 2011; 19: 331-9.

15. Colombo JR Jr, Santos B, Hafron J, Gianduzzo T, Haber GP, Kaouk $\mathrm{JH}$. Robotic assisted radical prostatectomy: surgical techniques and outcomes. Int Braz J Urol 2007; 33: 803-9. [CrossRef]

16. Kao TC, Cruess DF, Garner D, Foley J, Seay T, Friedrichs P. Multicenter patient self-reporting questionnaire on impotence, incontinence and stricture after radical prostatectomy. J Urol 2000; 163: 858-64. [CrossRef]

17. Thüroff JW, Abrams P, Andersson KE, Artibani W, Chapple CR, Drake MJ, et al. EAU Guidelines on Urinary Incontinence. Actas Urol Esp 2011; 35: 373-88. [CrossRef]

18. Lai HH, Hsu El, Boone TB. Urodynamic testing in evaluation of postradical prostatectomy incontinence before artificial urinary sphincter implantation. Urology 2009; 73: 1264-9. [CrossRef]

19. Griffiths DJ. Pressure-flow studies of micturition. Urol Clin North Am 1996; 23: 279-97. [CrossRef]

20. Han JS, Brucker BM, Demirtas A, Fong E, Nitti VW. Treatment of post-prostatectomy incontinence with male slings in patients with impaired detrusor contractility on urodynamics and/or who perform Valsalva voiding. J Urol 2011; 186: 1370-5. [CrossRef]

21. Lai HH, Boone TB. Implantation of artificial urinary sphincter in patients with post-prostatectomy incontinence, and preoperative overactive bladder and mixed symptoms. J Urol 2011; 185: 2254-9. [CrossRef]

22. Filocamo MT, Li Marzi V, Del Popolo G, Cecconi F, Marzocco M, Tosto $A$, et al Effectiveness of early pelvic floor rehabilitation treatment for post-prostatectomy incontinence. Eur Urol 2005; 48: 734-8. [CrossRef]

23. Daneshgari F, Moy ML. Current indications for neuromodulation. Urol Clin North Am 2005; 32: 37-40. [CrossRef]

24. Chapple CR. Duloxetine for male stress incontinence. Eur urol 2006; 49: 958-60. [CrossRef]

25. Kuo HC. Urodynamic evidence of effectiveness of Botulinum A toxin injection in treatment of detrusor overactivity refractory to anticholinergic agents. Urology 2004; 63: 868-72. [CrossRef]

26. Onur R, Orhan I. Radikal prostatektomi sonrası oluşan idrar kaçırma patogenezi ve güncel tedavi yaklaşımları. Fırat Tıp Dergisi 2008; 13: 80-7.

27. Madjar S. The role of intrinsic sphincteric deficiency diagnosis in the era of midurethral sling. Curr Urol Rep 2011; 12: 387-92. [CrossRef]

28. Smith DN, Appell RA, Rackley RR, Winters JC. Collagen injection therapy for post-prostatectomy incontinence. J Urol 1998; 160: 364-7. [CrossRef]
29. Cespedes RD, Leng WW, McGuire EJ. Collagen injection therapyfor postprostatectomy incontinence. Urology 1999; 54: 597-602. [CrossRef]

30. Berry JL. Evaluation of a new procedure for correction of postprostatectomy urinary incontinence. Bull NY Acad Med 1964; 40: 790-4.

31. Kaufman JJ. Urethral compression operations fort he treatment of post-prostatectomy incontinence. J Urol 1973: 110; 93-6.

32. Kishev SV. Suprapubic wad suspension. Combined perineal-abdominal approach for correction of postprostatectomy urinary incontinence. Urology 1978: 11; 28-32. [CrossRef]

33. Comiter CV. Male perineal sling: intermediate-term results. Neurourol Urodyn 2005: 24; 648-53. [CrossRef]

34. Guimarães M, Oliveira R, Pinto R, Soares A, Maia E, Botelho F, et al. Intermediate-term results, up to 4 years, of a bone-anchored male perineal sling for treating male stress urinary incontinence after prostate surgery. BJU Int 2009: 103; 500-4. [CrossRef]

35. Grimsby GM, Tyson MD, Wolter CE. Early outcomes of the transobturator male sling based on body mass index. Can J Urol 2012; 19: 6088-93.

36. Romano SV, Metrebian SE, Vaz F, Muller V, D'Ancona CA, Souza EA, et al. An adjustable male sling for treating urinary incontinence after prostatectomy: a phase III multicentre trial. BJU int 2006: 97; 533-9. [CrossRef]

37. Trigo-Rocha F, Gomes CM, Pompeo AC, Lucon AM, Arap S. Prospective study evaluating efficacy and safety of Adjustable Continence Therapy (ProACT) for post radical prostatectomy urinary incontinence. Urology 2006; 67: 965-9. [CrossRef]

38. Kocjancic E, Crivellaro S, Ranzoni S, Bonvini D, Gontero P, Frea B. Adjustable Continence Therapy for the treatment of male stress urinary incontinence: a single-centre study. Scand J Urol Nephrol 2007; 41: 324-8. [CrossRef]

39. Mundy AR, Stephenson TP. Selection of patients for implantation of the Brantley Scott artificial urinary sphincter. Br J Urol 1984; 56: 717-20. [CrossRef]

40. Tse V, Stone AR. Incontinence after prostatectomy: the artificial urinary sphincter. BJU Int 2003; 92: 886-9. [CrossRef]

41. Montague DK, Argermeier KW. Post prostatectomy urinary incontinence: the case for artificial urinary sphincter implantation. Urology 2000; 55: 2-4. [CrossRef]

42. Perez-Abadia G, Van Aalst VC, Palacio MM, Werker PM, Ren X, Van Savage J, et al. Gracilis muscle neosphincter for treating urinary incontinence. Microsurgery 2001; 21: 271-80. [CrossRef]

43. Rehder P, Gozzi C. Transobturator sling suspension for male urinary incontinence including post-radical prostatectomy. Eur Urol 2007; 52: 860-7. [CrossRef]

44. Strasser H, Marksteiner R, Margreiter E, Mitterberger M, Pinggera GM, Frauscher F, et al. Transurethral ultrasonography-guided injection of adult autologous stem cells versus transurethral endoscopic injection of collagen in treatment of urinary incontinence. World $J$ Urol 2007; 25: 385-92. [CrossRef]

45. Mitterberger M, Marksteiner R, Margreiter E, Pinggera GM, Frauscher $\mathrm{F}$, Ulmer $\mathrm{H}$, et al. Myoblast and fibroblast therapy for postprostatectomy urinary incontinence: 1-year followup of 63 patients. J Urol 2008; 179: 226-31. [CrossRef] 